\title{
COMPARISON OF MAGNETIC SEPARATION AND FLOTATION RESULTS FOR BENEFICIATION OF EMET COLEMANITE ORES
}

\author{
S. G. OZKAN* \\ Istanbul University, Engineering Faculty, Mining Eng. Dept., 34850, \\ Avcilar, Istanbul, Turkey
}

(Received 17 May 2000; In final form 5 July 2000)

Colemanite $\left(2 \mathrm{CaO} 3 \mathrm{~B}_{2} \mathrm{O}_{3} 5 \mathrm{H}_{2} \mathrm{O}\right)$ is one of the commercially preferable borates for many industries, such as agricultural, metallurgical, nuclear and production of fibreglass, borosilicate glasses, soaps, detergents, fire retardants, enamels and frits, used directly or after being transformed to boric acid $\left(\mathrm{H}_{3} \mathrm{BO}_{3}\right)$. This paper aims mainly to investigate the practical floatability of colemanite from the Emet deposits of Turkey using a conventional collector and to compare the concentration results with dry magnetic separation tests applied at high intensity.

Keywords: Colemanite; Borates; Boron; Emet; Flotation; Magnetic separation; AP825

\section{INTRODUCTION}

Although there are at least 150 minerals known to contain elemental boron, few of the boron minerals are mined as an ore in nature. Boron is naturally found in oxide type minerals containing some alkali ions, i.e., colemanite $\left(2 \mathrm{CaO} 3 \mathrm{~B}_{2} \mathrm{O}_{3} 5 \mathrm{H}_{2} \mathrm{O}\right)$, tincal $\left(\mathrm{Na}_{2} \mathrm{O} \quad 2 \mathrm{~B}_{2} \mathrm{O}_{3} \quad 10 \mathrm{H}_{2} \mathrm{O}\right)$ and ulexite $\left(\mathrm{Na}_{2} \mathrm{O} 2 \mathrm{CaO} 5 \mathrm{~B}_{2} \mathrm{O}_{3} 16 \mathrm{H}_{2} \mathrm{O}\right)$. Colemanite is a preferred calcium-bearing borate used mainly for production of fiberglass, borosilicate glasses, soaps, detergents, fire retardants, enamels, frits and

\footnotetext{
*e-mail: sgozkan@istanbul.edu.tr
} 
the agricultural, metallurgical and nuclear industries, directly or after being transformed to boric acid $\left(\mathrm{H}_{3} \mathrm{BO}_{3}\right)[1,2]$.

Emet is one of the important boron minerals production areas situated in the western Anatolia in Turkey. Emet colemanite reserves are exploited by Eti-Holding (formerly known as Etibank) for boric acid production at the company's Bandirma plant today. The company plans to operate its second boric acid production facility nearby Emet region in the very near future. Therefore the quality of colemanite is now a main objective of the company and alternative concentration methods are currently being investigated by several researchers [3-6].

\section{MATERIAL AND METHODS}

\section{Source of the Material}

The test samples used in this study were supplied from the EtiHolding's Emet Colemanite Mine (formerly known as Etibank) in Turkey. A geological section of the place where the samples were taken was constructed and investigated by taking hand samples. One fact that should be considered is that the samples provided were taken from the Bottom Section of the Hisarcik open pit mine by Eti-Holding's authorities [1].

X-ray diffraction analyses showed that the sample consists mainly of colemanite as a major mineral and some calcite, chlorite, montmorillonite, illite, realgar and orpiment as minor minerals. Complete chemical analyses also confirmed that the main constituent of the present sample is colemanite and the results are given in Table I in detail.

\section{Sample Preparation}

Approximately $50 \mathrm{~kg}$ of the colemanite ore sample, sized at $-250 \mathrm{~mm}$, were first crushed to $-50 \mathrm{~mm}$ with a primary jaw crusher, then quartered four times. One-fourth of the sample was saved for records; the rest was crushed to $-10 \mathrm{~mm}$ through a secondary jaw crusher. Crushed samples were passed through a tertiary roll crusher in order 
TABLE I Complete chemical analysis results of representative colemanite samples

\begin{tabular}{lclc}
\hline Components & Weight $\%$ & Method used & Precision $\pm \%$ \\
\hline $\mathrm{B}_{2} \mathrm{O}_{3}$ & 40.50 & Volumetric & 0.20 \\
$\mathrm{CaO}$ & 22.70 & Volumetric & 0.20 \\
$\mathrm{LOI}^{*}$ or $\mathrm{H}_{2} \mathrm{O}$ & 19.44 & Mass & 0.10 \\
$\mathrm{SiO}_{2}$ & 5.37 & A.A.S. & 1.50 \\
$\mathrm{As}_{2} \mathrm{O}_{3}$ & 1.32 & A.A.S. & 0.70 \\
$\mathrm{SrO}$ & 1.80 & A.A.S. & 0.70 \\
$\mathrm{MgO}$ & 2.37 & A.A.S. & 1.00 \\
$\mathrm{Al}_{2} \mathrm{O}_{3}$ & 1.50 & A.A.S. & 1.50 \\
$\mathrm{CO}_{3}$ & $<.50$ & Absorption & 2.00 \\
$\mathrm{Fe}_{2} \mathrm{O}_{3}$ & 1.56 & A.A.S. & 0.70 \\
$\mathrm{TiO}_{2}$ & 0.24 & A.A.S. & 1.00 \\
$\mathrm{SO}_{4}$ & 0.39 & Gravimetric & 0.50 \\
$\mathrm{~K}_{2} \mathrm{O}$ & 0.42 & A.E.S. & 0.70 \\
$\mathrm{Na}_{2} \mathrm{O}$ & 0.27 & A.E.S. & 0.70 \\
$\mathrm{SO}_{3}$ & 0.09 & Volumetric & 3.00 \\
$\mathrm{MnO}_{2}$ & $<0.01$ & A.A.S. & 0.70 \\
\hline
\end{tabular}

${ }^{*}$ Loss on ignition (at max. $750^{\circ} \mathrm{C}$ ).

to obtain convenient particle sizes for grinding tests. A laboratory rod mill was used to grind samples into different particle sizes over different time periods.

\section{Laboratory Apparatus and Reagent Preparation}

Batch flotation tests were conducted in a Denver Sub2A type flotation machine with an impeller speed of 1,250 RPM and a cell capacity of 2 litres. Izmir tap water was utilised at ambient temperature, i.e., $25 \pm 5^{\circ} \mathrm{C}$ in all trials. Unless otherwise required, $30 \%$ solid/liquid ratio, natural $\mathrm{pH}$ value of the slurry, i.e., about 8.5-9.0, no activator, no depressant and no other regulator were employed, while $100 \mathrm{~g} / \mathrm{t}$ of pine oil as frother at $1 \%$ concentration and conditioning and flotation times of 10 minutes per stage were utilised.

Prior to flotation tests, representative colemanite samples were ground in a rod mill and sieved at $-210 \mu \mathrm{m}$. For desliming a $38 \mu \mathrm{m}$ aperture sieve was utilised.

Batch magnetic separation tests were performed by use of a rareearth permanent magnetic roll separator obtained from Inprosys Corp. The magnetic roll is made up of a stack of relatively thin $(3-12 \mathrm{~mm})$ magnet discs (NdFeB type) interleaved with magnetically soft iron discs. The magnetic roll with dimensions of $300 \times 80 \mathrm{~mm}$ is 
enveloped with a thin abrasion-resistant belt, which is supported by an idler roll. Despite the open-type separator the magnetic field gradient is remarkably high due to relatively small dimensions of the iron discs and the high degree of magnetisation. This is ascribed to the absence of air gap which also provides an opportunity to process relatively coarse particles.

The feed rate, the angle of splitters, and the roll speed of the separator can be conveniently adjusted to optimise the separation conditions. Magnetic intensity for each trial was adjusted by implementing a new magnet with larger or smaller dimensions. A gaussmeter was used to measure and control the magnetic field strength accurately during the tests. In each test a sample of $200 \mathrm{~g}$ was fed into the feeder and the resultant magnetic and non-magnetic fractions were collected and analysed for their boron contents.

\section{EXPERIMENTAL STUDIES}

\section{Batch Flotation Tests}

The main aim of the first part of this study is to investigate the practical floatability of colemanite from the Emet deposits of Turkey using a conventional collector, i.e., AP825 and to determine the optimal dosages for this reagent.

Firstly, a number of colemanite flotation reagents were obtained from the Cyanamid company (presently known as Cytec Corp.). Conventional colemanite flotation reagents are mainly anionic type sulphonates, some fatty acids and petroleum products. Aeropromoter 825 (AP825) from Cyanamid, which has an alkyl sulphonate structure, is known to be an efficient collector for colemanite and as AP825 is exemplified as a conventional colemanite flotation reagent in this study [7-9].

The collector dosage was taken as a main variable for the batch flotation tests, since colemanite is known to be floatable with only collector addition. This criterion is dependent upon the fact that the selectivity is mainly due to the strength of the collector, when colemanite flotation is considered with only collector addition, although there are some frothers, depressants and other regulators 
known to be important variables during flotation of a non-metallic mineral. In addition to the tests with collector types and dosages, the effects of feed particle size, solid/liquid ratio of the slurry and slimes coatings were also controlled thoroughly [1].

\section{Determination of Optimal Dosage for AP825}

AP825 collector has an anionic type structure, specifically a sodium alkyl sulphonate and may be classified on the basis of alkyl and alkylaryl sulphonic acid and salts. These reagents could have following structural formula:

$$
R \mathrm{SO}_{3}^{-} \mathrm{M}^{+} \quad \text { Alkyl and alkyl-aryl sulphonic acid and salts }
$$

(namely sulphonates)

where $R$ represents an alkyl group which is $\mathrm{C}_{n} \mathrm{H}_{2 n+1}(n: 1,2,3, \ldots, n)$ and contains saturated $\mathrm{C}_{12}$ and $\mathrm{M}^{+}$represents a cation, i.e., $\mathrm{Na}^{+}, \mathrm{K}^{+}$ etc. These are stronger acids than the fatty acids and used in $5-20 \%$ solutions. Organic sulphonates are used to float oxides and silicates such as iron ores, chromite, garnet, beryl and zircon, as well as some salt type minerals. Because bonding is usually electrostatic, $\mathrm{pH}$ of the pulp is critical especially for the lower molecular weight collectors where chain-chain interaction is less important. Because of $\mathrm{C}-\mathrm{S}$ bond, alkyl sulphonates are more stable to hydrolysis than the alkyl sulphates.

AP825, commercially produced by Cyanamid is known to be very efficient as a collector for colemanite, as well as some other nonmetallic minerals, i.e., barite, celestite and kyanite according to literature. It is a very viscous, mahogany-brown colour liquid having a specific gravity of $1.1 \mathrm{~g} / \mathrm{cm}^{3}$ at $15.6^{\circ} \mathrm{C}$ [8].

A set of batch flotation tests for determination of optimal dosage for AP825 was performed on the deslimed colemanite ore samples at level of $250,500,750,1,000,1,500$ and $2,000 \mathrm{~g} / \mathrm{t}$. In addition, a $100 \mathrm{~g} / \mathrm{t}$ of pine oil was employed. The other variables were kept constant, particle size $-210+38 \mu \mathrm{m}$, solid liquid ratio $30 \%$, conditioning and flotation times of 10 minutes per stage.

Test results are given in Figure 1 showing grade and recovery graphs against dosages. 


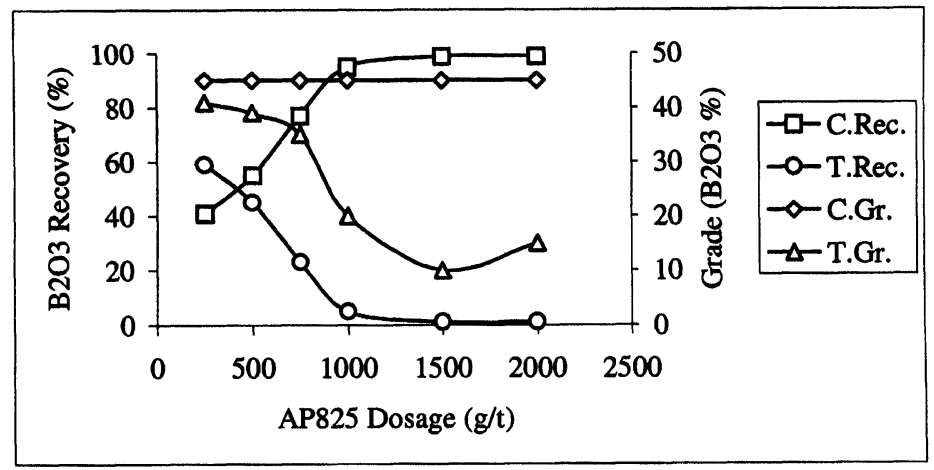

FIGURE 1 Comparison of AP825 dosages versus $\mathrm{B}_{2} \mathrm{O}_{3}$ recovery (\%) and grade $\left(\mathrm{B}_{2} \mathrm{O}_{3} \%\right)$.

The feed grades were found to be $43 \% \mathrm{~B}_{2} \mathrm{O}_{3}$ prior to flotation, and $40 \% \mathrm{~B}_{2} \mathrm{O}_{3}$ prior to the desliming stage. From Figure 1, the acceptable dosage for AP825 was found to be $1,500 \mathrm{~g} / \mathrm{t}$. Although the concentrate grade is just above the feed grade, yield and recovery data clearly show that almost all of the feed material is floated, when this amount of collector is employed. There is a noteworthy decrease in the tailing grade, when the dosage is increased, although $20 \% \mathrm{~B}_{2} \mathrm{O}_{3}$ of final tailing grade is still fairly high.

\section{Magnetic Separation Tests}

Previously ground colemanite ore sample at $-210 \mu \mathrm{m}$ was similarly deslimed at $-38 \mu \mathrm{m}$ and separated from its gangue minerals by a high intensity dry magnetic separation. In order to optimise the magnetic intensity, various parameters were investigated during the experiments.

Figure 2 shows magnetic separation results of the present colemanite ore samples in detail. The feed grade was calculated as about $40 \% \mathrm{~B}_{2} \mathrm{O}_{3}$ prior to desliming and about $43 \% \mathrm{~B}_{2} \mathrm{O}_{3}$ prior to magnetic separation. In Figure 2, it is clearly seen that while the recovery values for non-magnetic products (concentrate) were fairly low, the grade values did not significantly change during the tests. However, the grade values of the tailings decreased, when the intensity was increased. 


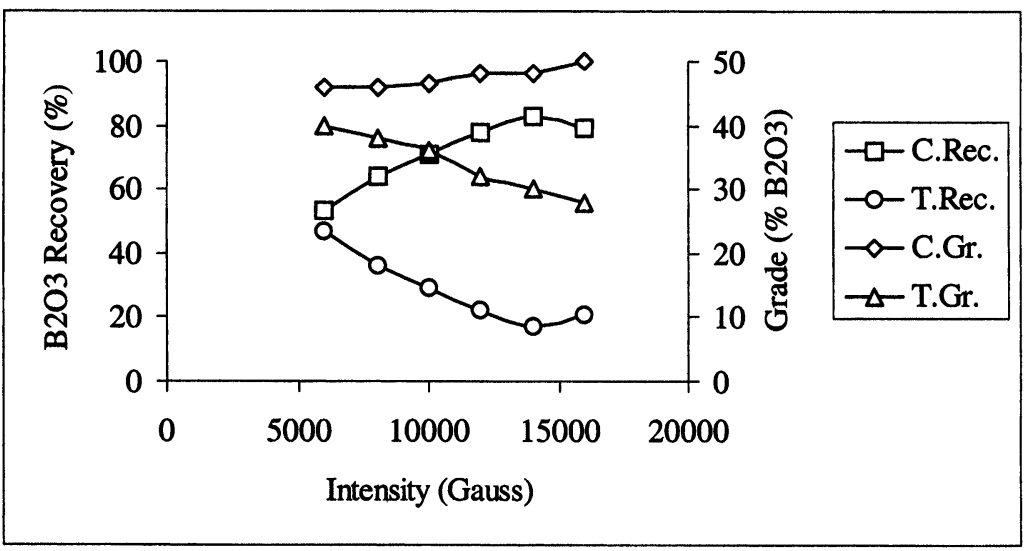

FIGURE 2 Comparison of magnetic intensities versus $\mathrm{B}_{2} \mathrm{O}_{3}$ recovery (\%) and grade $\left(\mathrm{B}_{2} \mathrm{O}_{3} \%\right)$.

\section{DISCUSSION AND CONCLUSION}

This study initially aims at revealing crucial information about the processing of colemanite which is a valuable export material of EtiHolding of Turkey. The question is whether this particular mineral should be beneficiated by wet or dry processing techniques. Previous studies partly answer this question that any concentration method could be applied to colemanite ores. There are obvious advantages and disadvantages of both wet and dry methods in terms of practical work, material losses, unit cost and etc.

A simple approach in terms of determination of the grade and recovery values of the products after the application of wet and dry processing methods was used in this study. Firstly, a conventional and well-known wet concentration technique, i.e., flotation was applied to the representative ore samples provided from Emet colemanite deposits of Turkey. As a result, an optimal dosage of the collector was determined as it was thought to be crucial for the method, while other parameters which were obtained from previous studies were kept constant. AP825 which is sodium sulphonate was found to be efficient for flotation of colemanite when it was applied at a dosage of $1,500 \mathrm{~g} / \mathrm{t}$. The higher dosages of AP825 did not necessarily increase either the grade or the recovery values of the concentrate. It can be seen that 
colemanite from the Emet deposits of Turkey is floatable under certain conditions which involve acceptable values of collector dosages, feed particle size, solid/liquid ratio, if a desliming step is taken prior to application of flotation tests. Material losses due to desliming are unavoidable if the high values of concentrate grade and recovery are targeted. Secondly, a dry beneficiation method, i.e., high intensity magnetic separation was applied to the colemanite ore samples properties of which were similar to previous experiments. The results of the magnetic separation tests showed that although the recovery values of concentrate were not desirable in terms of their $\mathrm{B}_{2} \mathrm{O}_{3}$ contents, the higher $\mathrm{B}_{2} \mathrm{O}_{3} \%$ grade values than the previous flotation experiments were obtained when the intensity of the magnetic separator was increased.

Finally it is clearly seen that when flotation is applied to colemanite the recovery of the concentrate is obviously higher than the ones from magnetic separation. However, when the higher grade values are targeted, the magnetic separation tests produce the desirable values.

On the other hand, the grade values of the tailings cannot be effectively reduced to acceptable amounts either with flotation or with magnetic separation. Therefore, this comparison study should be widened to investigate and determinate desirable values of the tailings grade.

\section{References}

[1] Ozkan, S. G. (1994). Flotation studies of colemanite ores from Emet deposits of Turkey, Ph.D. Thesis, The University of Birmingham, Birmingham, England, $208 \mathrm{p}$.

[2] Celik, M. S. et al. (1993). Flotation of boron minerals, Minerals and Metallurgical Processing, 10(3), 149-153.

[3] Kaytaz, Y. et al. (1986). Beneficiation of Bigadic colemanite tailings, In: Aytekin, Y. Ed., The Proceedings of the 1st International Mineral Processing Symposium, Izmir, Turkey, pp. 237-249 (in Turkish).

[4] Lyday, P. A. (1999). Boron 1998 Annual Report, US Geological Survey, Minerals Information, Virginia, USA.

[5] Onal, G. et al. (1991). Beneficiation of boron minerals in Turkey. In: The 17th International Mineral Processing Congress, Dresden, 4, 331-337.

[6] Ozdag, H. et al. (1988). Beneficiation of boron from tailings of Kestelek concentrator. In: Aytekin, Y. and Ipekoglu, U. Eds. The Proceedings of the 2nd International Mineral Processing Symposium, Izmir, Turkey, pp. 281-288 (in Turkish).

[7] Yarar, B. (1971). Beneficiation of colemanite by flotation. The Scientific and Technical Research Council of Turkey (Tubitak), Project No: 228, Ankara, Turkey (in Turkish). 
[8] Anon (1989). Cyanamid's Mining Chemicals Handbook, Mineral Dressing Notes: 26, Revised and Extended edition, USA.

[9] Atak, S. (1982). Flotation Principles and Applications, Istanbul Technical University Books, First edn., Istanbul, Turkey, pp. 206-207 (in Turkish).

\section{BIOGRAPHY}

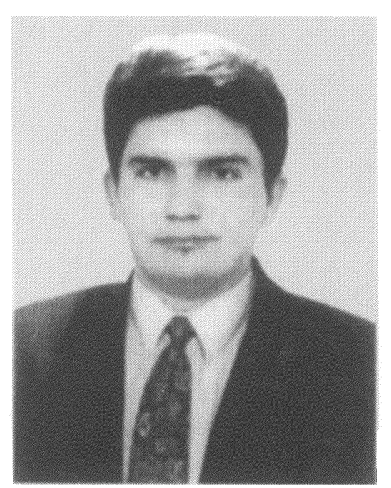

Safak G. Ozkan was born in Aydin in 1969. He graduated from the Mining Engineering Department of the Dokuz Eylul University in Izmir in 1990. He was then awarded a scholarship from Etibank to study for a masters degree in Mineral Processing in England. He completed his master program in 1993 and was awarded Ph.D. degree in Minerals Engineering in 1994 by the University of Birmingham in England for his research into flotation of colemanite ores from the Emet deposits of Turkey. Dr. Ozkan worked as a Research Engineer at the Boron Research Centre in Izmir between 1994 and 1998, and then was appointed an Assistant Professor at the Mineral Processing Division of the Mining Engineering Department of the Istanbul University. Dr. Ozkan is married with a daughter. 